\title{
Risk perception matters: why women's passion may not lead to a business start-up
}

\author{
Cecilia Dalborg and Yvonne von Friedrichs \\ Mid Sweden University, Östersund, Sweden, and \\ Joakim Wincent \\ Luleå University of Technology, Luleå, Sweden
}

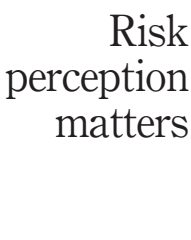

87

Received 7 January 2013 Revised 19 May 2013 15 August 2013 14 May 2014 Accepted 19July 2014

\begin{abstract}
Purpose - This paper aims to explore whether nascent women entrepreneurs perceive more risks than men, and to determine how higher risk perceptions might limit start-up decisions by mediating the potential influence of passion and self-efficacy.

Design/methodology/approach - This study surveyed 103 participants in Sweden - both women and men - who, in the period 2008 through 2011, intended to start a business. ANOVA tests and binominal logistic regression models were conducted to test hypothesized framework.

Findings - The authors found that nascent women entrepreneurs perceive more risk than nascent male entrepreneurs, that risk perceptions influence start-up decisions and that risk preferences partial out the otherwise identified influence of passion on start-up decisions.

Research limitations/implications - The authors reveal a consequence of gender socialization and how it impacts the start-up decisions of nascent women entrepreneurs. Support systems should consider developing activities that change the public's perception of who is an entrepreneur and seek ways to balance risk perceptions between men and women.

Originality/value - The authors argue here that risk perceptions play a prominent role in start-up decisions. Specifically, they consider that nascent women entrepreneurs perceive more risks than men, and that their view of risk partials out any potential influence of their perceived passion and self-efficacy on their start-up decision.
\end{abstract}

Keywords Risk perception, Self-efficacy, Passion, Nascent entrepreneurs, Women entrepreneurship Paper type Research paper

\section{Introduction}

Starting a new venture is perhaps one of the most important decisions an individual can make. Although various factors such as economic development, culture, and technology are important for understanding the creation of new ventures (Acs et al., 2005; Reynolds, 2011), it has been reported that individual factors such as motivation and confidence have the highest impact on the complex decision to start new businesses (Arenius and Minniti, 2005; Minniti and Nardone, 2007; Shaver and Scott, 1991). Given the importance of differences related to perceptions for the start-up decision, it is interesting that a substantial number of studies confirm that fewer women than men run companies (Allen et al., 2008; Brush et al., 2006; Buttner and Moore, 1997; Kelley et al., 2012; Marlow et al., 2009; Morris et al., 2006). For example, women-owned businesses as a percentage of total businesses in Canada amount to 15 per cent; in the USA, 26 per cent; in Denmark, 30 per cent and in New Zealand, 38 per cent (Brush et al., 2006, p. 6). This imbalance may

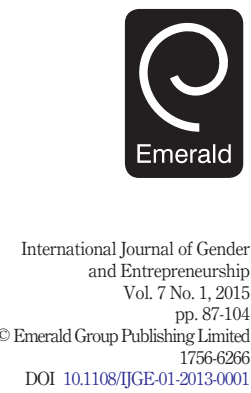


IJGE 7,1

be because of gender-related differences in subjective perceptions (Langowitz and Minniti, 2007; Minniti et al., 2005; Winn, 2005). Although women entrepreneur's perceptions, including those related to judgments of their own capabilities, motivation and attitude towards risk, may influence a large portion of the variation in start-up decisions (Zhao et al. 2005); research has yet to examine the exact relative contribution of such variables. In the present study, we posit that differences in risk perceptions play a central role, and we suggest that these differences may play an important role compared to other perception factors.

The aim of this study is to identify how risk perceptions among nascent women entrepreneurs contribute to understanding women's start-up decisions, and to explore whether risk perceptions might partial out any influence of passion and self-efficacy on the start-up decision. The paper is organized as follows. We next present our theoretical background, in which we hypothesize that nascent women entrepreneurs perceive more risks than men. We argue that their view of risk neutralizes any potential benefit that can be drawn from their motivation (passion) and their own perceived ability (self-efficacy) when contemplating a business start-up. Following the hypotheses, we present our sample of 103 women and men, who during the period 2008-2011 stated that they intended to start a business. Finally, we present the results and implications of our study.

\section{Theory and hypotheses}

Risk perceptions, entrepreneurship and gender

From its earliest studies, research on entrepreneurship has considered entrepreneurs to be risk takers, assuming they have a greater propensity to take risks than individuals in general (Cantillon, 1931, as cited in Hébert and Link, 1989). Risk relates to the difficulty of predicting future outcomes. Expected outcomes could be both positive and negative, but the crucial questions are "How much could I win?" or "How bad could it get?" (Sitkin and Pablo, 1992, p. 11). In becoming an entrepreneur, an individual risks his/her financial, social and psychic well-being (Liles, 1974). Several reasons explain why someone might be willing to take these risks (Segal et al., 2005); indeed, some entrepreneurs highlight the expected benefits of the risks (Weber et al., 2002); others are convinced they can control the risks (Boyd and Vozikis, 1994); and some do not perceive risk as being as grave as others view it (Busenitz, 1999; Simon et al., 2000; Weber et al., 2002); and some are more tolerant of risk in general (Segal et al., 2005). It has been difficult to find evidence to support the view that entrepreneurs have a greater propensity to tolerate risk than average people in a given population. Rather, extant literatures suggest that entrepreneurs perceive risk differently (Brockhaus, 1980; Busenitz and Barney, 1997; Low and Macmillan, 1988).

Risk perception concerns how individuals assess the risk inherent to a particular situation (Sitkin and Pablo, 1992; Sitkin and Weingart, 1995), and has been defined as "a subjective interpretation of expected loss" (Brindley, 2005, p. 145). Even when individuals are exposed to the same events and circumstances, they will view them with different eyes, which results in different risk perceptions (Sitkin and Pablo, 1992; Ritchie and Brindley, 2001). Differences in risk perception may result, in turn, in some individuals (here, entrepreneurs) choosing riskier paths because they believe they can master them (Busenitz, 1999). Mills and Pawson's (2012) literature survey confirmed that risk-taking is a critical variable for understanding enterprising behaviour, and they 
consider the variable to be a cornerstone of any decision to start a business. This is consistent with other previous research that has demonstrated a significant relationship between risk tolerance and entrepreneurial behaviour (Barbosa et al., 2007; Karakowsky and Elangovan, 2001; Keh et al., 2002; Sitkin and Pablo, 1992; Sitkin and Weingart, 1995). One reason businesses are launched may be because of the naive view of involved risks: "If entrepreneurs would carefully calculate all the risk involved in starting a new venture, most new ventures would never be started” (Busenitz, 1999, p. 337). Arenius and Minniti's (2005) findings confirm the negative connection between risk (fear of failure) and becoming an entrepreneur. A crucial variable related to start-ups is risk preference. Barbosa et al. (2007) found that potential entrepreneurs with high-risk preferences are more likely to start new businesses compared to those with lowerrisk preferences; those with high-risk preferences exhibit stronger entrepreneurial intentions. The cultural context here might play an important role because perception of risk can be reflected in the values that most members of a given society share collectively (Hofstede, 2001).

The concept of women and risk is a generally neglected field in entrepreneurship research, and existing studies "include" rather than "focus on" women (Brindley, 2005). Frequently, the literature claims that women are more affected by risk compared to men (Karakowsky and Elangovan, 2001; Kelley et al., 2011; Sexton and Bowman-Upton, 1990; Weber et al., 2002; Zinkhan and Karande, 1991); however, disagreement exists concerning how these risks affect women's behaviour. Some scholars have argued that women tend to be less risk-averse if their confidence is boosted, whereas others have indicated that gender differences in risk-taking are notable, despite the fact that women and men display similar traits (Brindley, 2005).

Why would women and men differ in their risk preferences? Karakowsky and Elangovan (2001) referred to social role theory, which holds "that gender differences in social behaviour originate from shared expectations or stereotypes about what is appropriate behaviour for men and women” (Karakowsky and Elangovan, 2001, p. 97). More recent inquiries have also acknowledged this notion. Marlow and McAdam (2011), for example, illustrated the impact of this type of binary gender system, or as Bruni et al. (2004, p. 256) highlighted, these "discourses on women entrepreneurs are linguistic practice that create true effects". Another reason women may be less risk-tolerant and perceive more risks than men could be their traditional role in taking responsibility for the family in that "putting the family's resources in danger, especially in a situation of necessity, may increase their perception of risk" (Langowitz and Minniti, 2007, p. 356). However, another reason for differences in risk preference might derive from the direct gender effects that still prevail and are linked to discrimination (Verheul and Thurik, 2001).

The broader literature on the gender marking of entrepreneurship (Ahl, 2002; Bruni et al., 2004) and gender socialization (Carter et al., 2007; Marlow and Patton, 2005) has demonstrated how gender shapes entrepreneurship, and evidences that women and men are treated differently, albeit often unconsciously. Hence, Brindley (2005, p. 156) argued that women reduce their risks by selecting industries in low-growth sectors of the economy and that this "makes them potentially more vulnerable to exogenous risk sources". This points to yet another explanation, suggesting that gender effects exist relating to how women and men entrepreneurs approach situations in which risks are involved. We agree with scholars who suggest that risk tolerance cannot be measured 
on a scale of good or bad; however, it is important to explore how risk affects different decisions (here, whether to start a business) and whether any gender differences are evident. If this is the case, it then becomes critical to identify what influences an individual's tolerance or aversion to risk (Karakowsky and Elangovan, 2001).

Passion, self-efficacy and risk perception

Worldwide, millions of new companies are started (Kelley et al., 2011). Researchers and entrepreneurs alike believe that one reason some individuals start companies can be explained by passion. The concept of passion can be traced far back in time. Even if disagreement has emerged regarding whether passion promotes or inhibits behaviour, most can agree with the view of passion "as any intense emotion that stirs humans with energy and deep longing to make difference" (Cardon et al., 2009, p. 515). Smilor (1997) suggested that entrepreneurial passion is one of the most observed phenomena in entrepreneurship research. Despite this acknowledgment, the research field singly lacks a theory-based definition of the concept. Cardon et al. (2009, p. 517) aimed to fill this gap by proposing a theory of entrepreneurial passion, conceptualizing the nature of the concept as:

[...] consciously accessible, intense positive feelings experienced by engagement in entrepreneurial activities associated with roles that are meaningful and salient to the self-identity of the entrepreneur.

Entrepreneurial commitment, fuelled by passion, encourages individuals to acquire the skills necessary to operationalize a business; thus, there is a positive correlation between passion and intensified entrepreneurial efforts (Baum and Locke, 2004). Moreover, entrepreneurs perceive their commitment as "something that relates to a meaningful and salient self-identity for them", making them more likely to embark on a venture (Cardon et al., 2009, p. 516).

The influence of passion on the decision to start a business is complex. Three types of business activity seem to be tied to passion: innovation, set-up and development. Although some entrepreneurs seem to be equally passionate about all three, others may consider one element to be more significant. The motivation to act (or not act) will depend on the level of passion for such activities (Baum and Locke, 2004), which is consistent with Smilor (1997, p. 342) who stresses the impulsive element in entrepreneurship:

Passion is the enthusiasm, joy, and even zeal that come from the energetic and unflagging pursuit of a worthy, challenging, and uplifting purpose. In the entrepreneur, it is described as drive - the determined, optimistic and persistent desire to succeed at one's own venture. It is the "fire in the belly" that makes the improbable possible.

Evidently, one might expect passion to have some influence on start-up decisions. Even though women seem to be as passionate about starting companies as men, it seems as if something holds them back from translating that keenness into a business. Start-up programmes intended to assist women in taking the step from passion to new venture have reported difficulties working with women, particularly concerns that their ability to help may be limited because of a low awareness of women's risk perception (Brindley, 2005). We suggest in the present study that the influence of passion could be extinguished by unfavourable risk preferences. 
Previous work has suggested that self-efficacy has an effect on start-up decisions (e.g. Arenius and Minniti, 2005; Boyd and Vozikis, 1994; Chen et al., 1998; Dabic et al., 2012; Krueger et al., 2000). Compared to a job with a fixed monthly income, self-employment can appear very challenging: "Starting and building an enterprise is like riding a roller coaster. One must endure constant and unseen ups and downs, turns and twists" (Smilor, 1997, p. 342). This implies that nascent entrepreneurs must have a strong belief in themselves or in other words a high degree of self-efficacy (Arenius and Minniti, 2005; Boyd and Vozikis, 1994; Chen et al., 1998; Krueger et al., 2000; Verheul et al., 2005).

A high level of perceived self-efficacy increases the likelihood that individuals will pursue and then persist in a given situation, unlike those with low self-efficacy. The relationship between self-efficacy and entrepreneurial plans has been found to influence start-up activity (Ajzen, 2002; Boyd and Vozikis, 1994; Krueger et al., 2000). Furthermore, although self-efficacy is not the only factor that affects such behaviour (an incentive to perform the particular task is also required), based on a combination of appropriate skills and adequate incentives, efficacy expectations constitute a determining factor in behaviour (Bandura, 1977). How people act in different situations is affected by their perceived ability far more than by actual ability. This can lead to self-limiting behaviours because many people believe they lack necessary elements to achieve a given task, even though they possess the required knowledge (Wood and Bandura, 1989). Therefore, it is likely that any influence exerted by self-efficacy on start-up decisions will be mitigated by unfavourable risk preferences. Although Langowitz and Minniti (2007) suggested that self-efficacy is an important covariate for entrepreneurship, many different views have been expressed about the links among self-efficacy, start-ups and gender. Some prior studies have indicated that women tend to have lower self-confidence with respect to entrepreneurship, and this, in turn, affects their business performance and advancement (Dickerson and Taylor, 2000; Fielden et al., 2003; Kirkwood, 2009; Langowitz and Minniti, 2007; Wilson et al., 2007). Others (e.g. Ljunggren and Kolvereid, 1996 and Zhao et al., 2005) have not been able to distinguish the influence of self-efficacy, remarking that it does not differ between women and men in their studies of nascent entrepreneurs.

Moreover, research has indicated that identified gender differences in entrepreneurial intentions persist even when women's entrepreneurial self-confidence is strengthened (Wilson et al., 2007). Indeed, this result challenges many of the existing conceptions about self-efficacy in entrepreneurship. We suggest in the present paper that these results emerge because risk preferences are crucial, and thus, they cancel out the effect of self-efficacy in the start-up decision. Given that women score lower than men when it comes to risk preferences, this could explain the limited results educational programmes measure when examining self-efficacy and their ability to encourage women's start-ups.

\section{Hypotheses}

Against the foregoing background, we observe that risk and how entrepreneurs perceive and interpret risk constitute an important theme in the entrepreneurship literature (Busenitz, 1999; Fletcher, 2010; Monsen and Urbig, 2009). The literature has argued that women generally tend to be more risk averse and conservative than men (Karakowsky and Elangovan, 2001; Sexton and Bowman-Upton, 1990; Zinkhan and 
IJGE 7,1

92

Karande, 1991; Weber et al., 2002). Perception of risk may be gender-related, but this area suffers from an under-developed conceptual basis, which may be problematic when attempting to understand how women make start-up decisions. In particular, women's views on risk - and the factors that influence their views - are crucial in understanding the development of women-owned and -operated businesses (Brindley, 2005; Fielden et al., 2003; Kirkwood, 2009). Furthermore, it seems that the characteristics associated with men's entrepreneurship are not consistent with women's (Delmar and Davidsson, 2000).

If one assumes that risk preferences play a key role in start-up decisions, several relationships require more research. A study by Cardon et al. (2009) confirmed that situations exist in which passion is inhibited and fails to result in new ventures; here, the authors call for further investigation. Self-efficacy is often singled out as one of the most important factors for understanding entrepreneurial behaviour (e.g. Arenius and Minniti, 2005; Boyd and Vozikis, 1994; Chen et al., 1998; Dabic et al., 2012; Krueger et al., 2000). However, Wilson et al.'s (2007) findings indicated that women are still less inclined to start a business than men, even though their self-efficacy can be strengthened with education. Clearly, gender differences in start-ups involve other components.

Knowledge of the relationship between self-efficacy and risk perception in start-up decisions is limited (Barbosa et al., 2007; Krueger and Dickson, 1994; Zhao et al., 2005). In the present study, we suggest that risk perceptions could be a key variable in the nomological network of perceptional variables that influence the start-up decision. This line of reasoning leads us to the following hypotheses:

H1. Nascent women entrepreneurs perceive more risks than nascent male entrepreneurs.

H2. Risk perceptions are manifested in start-up decisions.

$H 3 a b$. Risk perceptions cancel out the influence of $(a)$ passion and $(b)$ self-efficacy on start-up decisions.

\section{Method and analytical model \\ Sample}

The study's participants were women and men who, in the period covering 2008 through 2011, intended to start their own businesses. We identified these participants based on their contacts with the organization ALMI, a Swedish public company founded in 1994 to promote small business development. During the period 2008 through 2011, ALMI Företagspartner Mitt AB ran a project named "Arena för Entreprenörskap” (Arena for Entrepreneurship). The sample for the present study was drawn from participants in this project. During this period, 2,100 individuals (1,096 women and 1,004 men) consulted ALMI for advice and guidance about their business ideas, which later resulted in 728 new businesses.

With ALMI's support, we gained permission to execute a quantitative research design and subsequently emailed a questionnaire to 233 randomly selected project participants. The survey was sent in the spring of 2012 after the end of the project. Seventy-two people responded initially, and an additional 31 people responded after a reminder was sent. We received 103 valid answers - a response rate of 44 per cent. Among those who answered the questionnaire, 66 per cent were women, and 62 per cent of all the respondents had started a business. Compared with the entire sample, women 
who actually started a business responded to the questionnaire in greater numbers. Based on the responses, about 40 per cent did not go on to start a new business, even though everyone who participated in the programme had intended to become an entrepreneur.

Table I lists the respondents' characteristics. The average age of the respondents was 42 years. A high proportion (40 per cent) had parents who had been self-employed, and 30 per cent had run a business before they participated in the project. In terms of industry sector, the likelihood of starting businesses was greatest in the creative sector. Men tended to start businesses in the manufacturing/trade sector (50 per cent), whereas

\begin{tabular}{|c|c|c|c|c|c|c|c|}
\hline Characteristics & $\operatorname{All}(\%)$ & $\begin{array}{l}\text { Company } \\
\text { start-up (\%) }\end{array}$ & $\chi^{2}$ value & Women $(\%)$ & Men (\%) & $\chi^{2}$ value & \\
\hline $\begin{array}{l}\text { Age of owner } \\
\text { Under } 30 \text { years } \\
31-45 \text { years } \\
46-60 \text { years } \\
61 \text { years or older }\end{array}$ & $\begin{array}{r}18 \\
42 \\
37 \\
3\end{array}$ & $\begin{array}{l}82 \\
68 \\
51 \\
33\end{array}$ & $6.232 \#$ & $\begin{array}{r}16 \\
28 \\
41 \\
5\end{array}$ & $\begin{array}{l}22 \\
50 \\
28\end{array}$ & 3.661 & \\
\hline $\begin{array}{l}\text { Industrial sector } \\
\text { Agriculture } \\
\text { Business services } \\
\text { Construction/transport } \\
\text { Creative industry } \\
\text { Education } \\
\text { Manufacturing/trade } \\
\text { Personal services/health }\end{array}$ & $\begin{array}{r}7 \\
13 \\
5 \\
20 \\
5 \\
29 \\
21\end{array}$ & $\begin{array}{l}50 \\
75 \\
20 \\
79 \\
60 \\
63 \\
55\end{array}$ & 7.762 & $\begin{array}{r}8 \\
16 \\
5 \\
23 \\
6 \\
18 \\
24\end{array}$ & $\begin{array}{r}3 \\
6 \\
6 \\
16 \\
3 \\
50 \\
16\end{array}$ & 11.818\# & \\
\hline $\begin{array}{l}\text { Gender } \\
\text { Women } \\
\text { Men }\end{array}$ & $\begin{array}{l}66 \\
34\end{array}$ & $\begin{array}{l}61 \\
66\end{array}$ & 0.200 & & & & \\
\hline $\begin{array}{l}\text { Marital status } \\
\text { Married/cohabiting } \\
\text { Not married/cohabiting } \\
\text { Children } \\
\text { No children }\end{array}$ & $\begin{array}{l}70 \\
30 \\
67 \\
33\end{array}$ & $\begin{array}{l}67 \\
52 \\
60 \\
65\end{array}$ & $\begin{array}{l}2.059 \\
0.155\end{array}$ & $\begin{array}{l}73 \\
68\end{array}$ & $\begin{array}{l}63 \\
66\end{array}$ & $\begin{array}{l}1.210 \\
0.043\end{array}$ & \\
\hline $\begin{array}{l}\text { Experience } \\
\text { Entrepreneurial parents } \\
\text { No entrepreneurial parents } \\
\text { Own start-up experience } \\
\text { No industry experience }\end{array}$ & $\begin{array}{r}40 \\
60 \\
30 \\
9\end{array}$ & $\begin{array}{l}55 \\
68 \\
68 \\
40\end{array}$ & $\begin{array}{l}1.536 \\
0.728 \\
1.328\end{array}$ & $\begin{array}{l}37 \\
\\
27 \\
13\end{array}$ & $\begin{array}{r}47 \\
36 \\
0\end{array}$ & $\begin{array}{l}0.838 \\
\\
0.639 \\
2.676 \#\end{array}$ & \\
\hline $\begin{array}{l}\text { Activity before potential start-up } \\
\text { Employed } \\
\text { Self-employed } \\
\text { Unemployed } \\
\text { Parental leave/sick leave } \\
\text { Student } \\
\text { Note: Significant at: } \# p<0.1\end{array}$ & $\begin{array}{r}52 \\
4 \\
25 \\
5 \\
14\end{array}$ & $\begin{array}{l}68 \\
75 \\
63 \\
60 \\
39\end{array}$ & 6.001 & $\begin{array}{r}45 \\
5 \\
26 \\
8 \\
16\end{array}$ & $\begin{array}{r}66 \\
3 \\
22 \\
0 \\
9\end{array}$ & 5.928 & $\begin{array}{r}\text { Table I. } \\
\text { Respondents' } \\
\text { characteristics }\end{array}$ \\
\hline
\end{tabular}


IJGE

7,1

\section{4}

women started companies in the personal services/health (24 per cent) and creative sector (23 per cent). The majority of respondents were married (70 per cent) and had children (67 per cent). Being employed was the most common activity before the respondent's potential start-up (52 per cent).

To test the hypotheses, we created different measurements based on previous research.

\section{Dependent variable}

Start-up decision. In the survey, we asked whether the respondents had started a business. We coded the variable 1 if the respondent started a business after the programme and 0 if they did not start a business.

\section{Independent variables}

Risk preference. Risk preference refers to a general desire to accept or avoid risk. To explore risk preference, we adopted the same measure used in the Panel Study of Entrepreneurial Dynamics (PSED) (Reynolds, 2000). Respondents were asked:

Assuming you are the sole owner, which situation would you prefer? (i) A business that would provide a good living, but with little risk of failure, and little likelihood of making you a millionaire, or (ii) A business that was much more likely to make you a millionaire but had a much higher chance of going bankrupt.

Consistent with the PSED approach, we coded the first alternative as low risk with 0, and the second high-risk alternative with 1.

Passion. To understand the influence of the respondents' passion for entrepreneurship, we used items from Vallerand et al.'s (2003) passion scale, intended to capture extreme enthusiasm about an activity, otherwise known as obsessive passion (OP). To measure this, we created a mean value including five OP items reported in Study 1 of Vallerand et al. (2003), but replaced the generic term "this activity" with the specific phrase "starting a business". Thus, items used were:

- "I have difficulty imagining my life without starting a business [this activity]".

- "I am emotionally dependent on starting a business [this activity]".

- "I have a tough time controlling my need to start a business [do this activity]".

- "I have almost an obsessive feeling for starting a business [this activity]".

- "The urge is so strong. I can't help myself from starting a business [doing this activity]".

We used a 5-point scale anchored by 1 = strongly disagree to $5=$ strongly agree.

Entrepreneurial self-efficacy. We specifically asked how respondents perceived themselves managing the entrepreneurial process, which involved a gradual transition from business idea to livelihood. To measure this, we created an index of the following three questions:

(1) "I can face the challenges expected of an entrepreneur".

(2) "I believe I can feel good in this role even if my workload is increasing".

(3) "I think I can handle the role of entrepreneur even though the tasks are becoming more and more complex". 
Again, we used a 5-point scale anchored by $1=$ strongly disagree to $5=$ strongly agree.

\section{Control variables}

The control variables we used included:

- Age: We used year of birth as a measure of age.

- Gender: Women were coded 0, men 1.

- Previous experience with entrepreneurship: We used the condition of whether respondents had parents who were entrepreneurs and whether they had previous, personal experience in creating another business. Yes was coded 1 , and no 0.

We also controlled for industry effects, where we used the industries reported in Table I as input.

\section{Data analysis}

To examine whether nascent women entrepreneurs perceive more risks than nascent male entrepreneurs (H1), and whether risk perceptions are manifested in start-up decisions (H2), we conducted a one-way ANOVA test. To research whether risk perceptions cancelled out the influence of $(H 3 a)$ passion and $(H 3 b)$ self-efficacy on start-up decisions, we analysed our data using a binominal logistic regression model. In doing so, we validated the results of the previous hypotheses using an alternative analytical method. This regression estimates the probability that an event will occur. In our case, the event is the start-up decision. The logistic regressions were performed in six steps. In the first step, we controlled for the influence of four of the respondents' characteristics on the likelihood that they might choose to start a business. In Steps 2 and 3, we added, first, passion and self-efficacy and, second, risk preferences to the variables used in Step 1. Steps 4 through 6 are extended with additional control variables to see how they affect the variables in previous regressions.

\section{Results}

To examine our first hypotheses, $H 1$, we initially conducted a one-way ANOVA test to determine whether nascent women entrepreneurs preferred different types of risk compared to nascent male entrepreneurs. We found support for H1: women and men indeed have different risk preferences $(F=4.869 *)$. Table II presents the result of the test.

To examine $H 2$, we tested the assumption that risk perception is evident in start-up decisions. The ANOVA test of these variables supports H2. As evident in Table III, the variable risk preference proves to be of significant importance on start-up decision $(F=8.466)$.

\begin{tabular}{lccr}
\hline Risk variables & Women $(\%)$ & Men $(\%)$ & $F$ value \\
\hline Risk preference & 11 & 29 & $4.869 *$ \\
Note: Significant at: $* p<0.05$ & & &
\end{tabular}

Table II. Gender and risk 
$\underset{7,1}{\text { IJGE }}$

96

As a formal test of the former hypotheses and $H 3 a b$, logistic regression analyses were conducted to determine whether (and if so, how) various risk factors cancel out passion for starting a business and entrepreneurial self-efficacy (Tables IV and V).

As indicated in Table IV, we identified a significant effect of passion when risks were not included in the analysis. When included, however, the risk variable cancelled out the effects of passion. Self-efficacy did not affect the start-up decision; this result was valid irrespective of the risk variable. As presented in Table $\mathrm{V}$, we then extended the regression with some additional control variables.

The results in Table $\mathrm{V}$ indicate that after testing the effects of the control variables, the independent variables such as passion and risk preference explained much of the variance in participants' start-up decisions $\left(\Delta R^{2}=12.7\right.$ per cent), with a significant, positive effect for passion in Step 5 and risk preference in Step 6. We did not observe significant sector effects, suggesting that the industry did not influence start-up decisions in this sample of nascent entrepreneurs. More importantly, we observe that passion has a significant effect when risks are not included in the analysis, but that the risk variable cancels out the effects of passion when it is included. We consider this will strike particularly hard on women's decisions to start businesses because the risk factors differ significantly according to gender, whereas we were unable to identify any differences in passion for

Table III.

Start-up decision and risk

\begin{tabular}{lccr}
\hline Risk variables & All $(\%)$ & Company start-up (\%) & $F$ value \\
\hline Risk preference & 17 & 94 & $8.466^{* *}$ \\
Note: & Significant at: ${ }^{* *} p<0.01$ & & \\
\hline
\end{tabular}

\begin{tabular}{lcrr}
\hline Variables & \multicolumn{1}{c}{ Step 1 } & \multicolumn{1}{c}{ Step 2 } & \multicolumn{1}{c}{ Step 3 } \\
\hline Control variables & & & \\
Age & $7.864^{* *}(0.024)$ & $6.403^{* *}(0.025)$ & $4.409 *(0.026)$ \\
Gender & $0.051(0.512)$ & $0.08(0.532)$ & $0.129(0.577)$ \\
Experience (parents') & $5.306^{*}(0.513)$ & $4.478^{*}(0.536)$ & $4.388^{*}(0.554)$ \\
Experience (own) & $3.306(0.570)$ & $1.676(0.606)$ & $0.300(0.647)$ \\
Independent variables & & & \\
Passion & & $3.555^{*}(0.270)$ & $1.640(0.287)$ \\
Self-efficacy & & $0.015(0.415)$ & $0.00(0.423)$ \\
Risk preference & & & $3.671 *(1.135)$ \\
Model diagnostics & & & \\
Overall $\chi^{2}$ & $12.689 * *$ & $16.41 * *$ & $20.601 * *$ \\
[df] for overall $\chi^{2}$ & {$[4]$} & {$[6]$} & {$[7]$} \\
Nagelkerke $R^{2}$ & 0.179 & 0.23 & 0.288 \\
Adjusted $R^{2}$ ((LL0-LL1)/LL0) & 0.106 & 0.1398 & 0.180 \\
$\Delta R^{2}$ & & & 0.074
\end{tabular}

Logistic regression results for Steps 1 through 3

Notes: Significant at: ${ }^{*} p<0.05$; ${ }^{* *} p<0.01$; standard errors are in parentheses 


\begin{tabular}{|c|c|c|c|c|}
\hline Variables & Step 4 & Step 5 & Step 6 & \multirow{6}{*}{$\begin{array}{r}\text { Risk } \\
\text { perception } \\
\text { matters }\end{array}$} \\
\hline \multicolumn{4}{|l|}{ Control variables } & \\
\hline Age & $11.101^{* * *}(0.028)$ & $8.254 * *(0.029)$ & $7.273^{* *}(0.033)$ & \\
\hline Gender & $0.473(0.617)$ & $0.872(0.660)$ & $2.052(0.755)$ & \\
\hline Experience (parents') & $5.987 *(0.600)$ & $4.123^{*}(0.607)$ & $3.132(0.638)$ & \\
\hline Experience (own) & $2.351(0.660)$ & 1.001 (0.693) & $0.124(0.806)$ & \\
\hline \multicolumn{4}{|l|}{ Industry } & \\
\hline Agriculture & $0.620(1.666)$ & $0.221(2.065)$ & $0.630(2.410)$ & \\
\hline Business services & $0.050(1.408)$ & $0.527(1.590)$ & $2.345(1.924)$ & \\
\hline Creative industry & $0.089(1.314)$ & $1.030(1.557)$ & $3.186(1.989)$ & \\
\hline Manufacturing/trade & $0.092(1.232)$ & $0.108(1.421)$ & $1.116(1.708)$ & \\
\hline Personal services/health & $0.208(1.241)$ & $0.011(1.356)$ & $0.325(1.638)$ & \\
\hline Transport/construction & 2.799 (1.805) & $1.050(2.108)$ & $0.299(2.192)$ & \\
\hline \multicolumn{5}{|l|}{ Employment } \\
\hline Employed & $6.462 * *(0.722)$ & $7.769 * *(0.803)$ & $9.395^{* *}(0.947)$ & \\
\hline Unemployed & $1.324(0.703)$ & $2.529(0.772)$ & $2.703(0.828)$ & \\
\hline \multicolumn{5}{|l|}{ Independent variables } \\
\hline Passion & & $3.744 *(0.370)$ & $3.252(0.418)$ & \\
\hline Self-efficacy & & $0.219(0.544)$ & $0.605(0.585)$ & \\
\hline Risk preference & & & $4.930 *(1.583)$ & \\
\hline \multicolumn{5}{|l|}{ Model diagnostics } \\
\hline Overall $\chi^{2}$ & $27.974^{* *}$ & $33.012 * *$ & $41.163 * * *$ & \\
\hline [df] for overall $\chi^{2}$ & {$[12]$} & {$[14]$} & {$[15]$} & \\
\hline Nagelkerke $R^{2}$ & 0.367 & 0.426 & 0.519 & \\
\hline Adjusted $R^{2}($ LLO-LL1)/LL0) & 0.236 & 0.284 & 0.363 & Table V. \\
\hline$\Delta R^{2}$ & & & 0.127 & Logistic regression \\
\hline \multicolumn{4}{|c|}{ Notes: Significant at: $* p<0.05 ; * * p<0.01 ; * * * p<0.001$; standard errors are in parentheses } & through 6 \\
\hline
\end{tabular}

business between women and men. Thus, our analyses above suggest support for $H 1, H 2$ and $H 3 a$, but not for $H 3 b$.

\section{Discussion}

Study contributions

The results from this study provide several insights for further discussion. Because research argues that risk perception variables are important for understanding start-up decisions, and that such effects can be assumed to interfere with women's propensity to start businesses, a study of risk perceptions is suggested as fruitful (Brindley, 2005; Gatewood et al., 2002; Minniti and Nardone, 2007). Our empirical data bear out the relevance of considering risk preferences. We thus argue that the significance of risk reported here should be acknowledged in start-up decision frameworks in which gender is considered (Brindley, 2005; Greene et al., 2006; Kirkwood, 2009; Minniti et al., 2005; Vejsiu, 2011). Following Karakowsky and Elangovan (2001), we argue that it is important to identify the sources of various risk preferences. Brindley (2005) echoed this when claiming that if you do not know how women view risk factors and what 
IJGE 7,1

98

influences them, it is difficult to offer support and advice to strengthen other characteristics.

Our non-significant results also contribute to the debate. Initially, we suspected that an individual's self-efficacy would be important for any start-up decision, but that emerged as untrue. The high level of self-efficacy reported in the sample suggested that the respondents all had more than enough self-efficacy to be entrepreneurs, and they considered themselves to have the abilities to cope with the tasks that entrepreneurship might bring. We found these results to be somewhat surprising because the variable self-efficacy, in particular, has proven important in identifying nascent women entrepreneurs (Fielden et al., 2003; Kirkwood, 2009; Langowitz and Minniti, 2007; Wilson et al., 2007). Reflecting on this, we now hold that self-efficacy may be linked to entrepreneurial intent, but perhaps not necessarily to the start-up decision per se. The present study certainly supports this line of reasoning. All respondents included in this study can be defined as nascent entrepreneurs, and the measured mean value for the variable self-efficacy is very high. This supports the assumption that self-efficacy is positively related to entrepreneurial intent. Nevertheless, when controlling for other factors, self-efficacy does not influence the decision to start a company, and it seems that self-efficacy does not contribute with insights into any gendered reasoning behind the final start-up decision. This is consistent with Zhao et al.'s (2005, p. 1270) results, who noted that, "Gender was not related to entrepreneurial self-efficacy [...]. Thus, our results suggest that the relationship of gender to entrepreneurial intentions is more complex than previously assumed". We also believe that the results of our study complement Carter et al. (2003), who reached similar conclusions: no gender differences were identified in variables such as independence, recognition or self-realization, meaning further research was required to reveal the cognitive variables that might explain existing gender differences in entrepreneurship.

Our results also bring fresh insights into passion research. We present an approach suggesting that women perceive entrepreneurship and its associated risk factors in a way that negatively affects the likelihood that they will turn their passion into a new company. Our results also indicate that passion is indeed a significant variable for start-up decisions. This is consistent with previous research that found that passion is a driving force in creating new businesses (Baum and Locke, 2004; Cardon et al., 2009). Entrepreneurship involves different roles, and the importance of self-identity in conceptualizing entrepreneurial passion and in understanding start-up decisions has already been recognized (Cardon et al., 2009). Nevertheless, the variable risk preference exhibits significant differences in terms of both start-up decisions and gender and, while noting that the risk variable cancels out the effects of passion whenever included, we believe this offers a significant addition to Cardon et al.'s (2009) argument.

\section{Implications for practice and policy}

The present study provides several new insights for practice. Our findings indicate that risk preferences have a significant impact on start-up decisions; we believe that women's entrepreneurship can be stimulated "by changing people's perception of the riskiness and benefits of decision alternatives, rather than by affecting their willingness to take on more or less risk" (Weber et al., 2002, p. 283). The way things are perceived is controlled by personal characteristics, some of which can be difficult to change. However, because this reflects subjective rather than objective conditions, it should be 
possible to influence risk preferences, even if this takes a long time (Arenius and Minniti, 2005; Minniti and Nardone, 2007). We believe that serious attention should be paid to the question of why women perceive risk in a way that mitigates their passion for starting $a$ business. It is imperative to recognize not only that gender socialization still shapes entrepreneurship but also the specific problems that this entails. In other words, according to Marlow and Patton (2005, p. 731), "it is time to move away from the debate about whether gender shapes entrepreneurship [...] to how, why, and in what manner it does this". This applies significantly to the people working within the policy support system. As previous studies have shown that women and men are assessed differently in counselling situations (Carter et al., 2007), it is important that the advisors themselves understand the impact of their advice and the implications of differences in treatment.

Furthermore, we believe that educators and start-up programmes for nascent entrepreneurs should give greater consideration to the question of risk preferences. Society at large holds many preconceived ideas about what women and men are expected to do (Bruni et al., 2004; Marlow and McAdam, 2011). The primary purpose of a business is to generate a surplus, a condition that women are just as capable of achieving as men. However, what female and male entrepreneurs include in their risk perceptions is something that educators and regulators could do well to acknowledge and discuss when developing venture support programmes. Obviously, having modules in start-up programmes in which risk is discussed and analysed may be something that could improve the start-up rates among nascent entrepreneurs. In the Swedish study context, there are situations in which remaining debt when undergoing bankruptcy can negatively influence personal income, property and savings. Re-evaluating such potential failure costs and the negative personal consequences of bankruptcy are things that potentially might influence risk preferences in a start-up situation. Furthermore, reducing the cost of registering a limited company and encouraging women to use this form of company over sole proprietorship are examples of how such risk could be limited.

\section{Limitations and further research}

The present study is not without limitations. Although we assessed the presence of common method bias in the data and did not find significant problems for our approach, the measurement quality is still open to question. We only measured self-efficacy with a few items, and other measurements should be used to test the relevance of our results further. We also believe that other risk perception measurements could be used. The term "good living" contained in this measurement could be interpreted differently, for example, and would benefit from being replaced with a more concrete concept, thus improving nomological validity.

A larger sample would provide more specific insights into how risk perceptions influence women and men. The number of respondents (women and men) is not low or fewer than in similar studies (Karakowsky and Elangovan, 2001; Simon et al., 2000), but the robustness of the results would improve by using a larger sample. We hope these limitations can be addressed in future research.

We also believe some of the limitations in our approach could prompt future research. First, differences in risk preference may also prove important for the way women and men run businesses in various sectors. Although we can only see a few instances of 
IJGE 7,1

significant gender difference $(p<0.1)$ in terms of industry sector, our study has not determined whether choice of industry relates to risk preferences.

Second, cultural contexts could suggest a need for further research on the extent to which our results are echoed in other countries. In the present study, we have analysed risk perceptions at an individual level in a Swedish context. According to Hofstede (2001), values such as risk perception are personal but are affected by the cultural context in which individuals grow up. Note that the ranking of the uncertainty avoidance aspect of Hofstede's cultural dimension for Sweden scores was quite low (Uncertainty avoidance index [UAI] $=29$ ) in a recent study by Hofstede et al. (2010). However, we argue that there are other countries where risk preferences might be even more problematic for start-up decisions. This suggests that the present study's results should be replicated in other national settings.

Third, our data allow us to control for different variables that have been decisive in whether a company actually launches. Therefore, we believe we have a valid sample with which to test the impact of risk perceptions on the ultimate decision to start a company. However, a longitudinal dimension would be of greatest interest and is something the present study fails to address.

Fourth, risk behaviours are considered a cornerstone of entrepreneurship, and therefore, the research on the relationship between risk factors and entrepreneurial activities is extensive (Mills and Pawson, 2012). However, the need still exists for more research in the field (Barbosa et al., 2007; Brindley, 2005; Zhao et al., 2005). Existing studies have less frequently acknowledged motivational constructs such as passion. In line with Cardon et al. (2005), our findings indicate that using such variables may prove fruitful; this leads us to call for further research on this topic.

Finally, our quantitative approach has limitations for understanding the relevance of risk preferences among women entrepreneurs. We encourage more qualitative work on risk perceptions, and we believe that a systematic and longitudinal study of nascent women entrepreneurs would reveal important insights into how perceptual variables influence women's start-up decisions.

\section{Conclusions}

The main purpose of the present study was to examine the ways in which risk perceptions impact women's decisions to start businesses. We tested three hypotheses to assess the importance of risk among nascent entrepreneurs. We found that nascent women entrepreneurs perceived more risks than nascent male entrepreneurs, and that risks perceptions influence start-up decisions. However, we also found that risk preference cancels out the otherwise evident influence of passion on start-up decisions. We did not find support for the hypothesis that risk perceptions cancel out the effect of self-efficacy on start-up decisions. Overall, our study's results support the notion that differences in start-up decisions between men and women may relate to perceptions of risk, and that such perceptions may dissuade women from translating their passion for entrepreneurship into actual businesses. Self-efficacy seems to play a marginal role in an approach in which risk and passion variables are included. Evidently, risk perceptions should not be neglected in any understanding of how nascent women entrepreneurs decide to move towards being an entrepreneur. Our hope is that the results of the present study inspire future work in this area. 


\section{References}

Acs, Z., Arenius, P., Hay, M. and Minniti, M. (2005), 2004 Global Entrepreneurship Monitor Executive Report, Babson College and London Business School, Babson Park, MA and London.

Ahl, H. (2002), "The making of the female entrepreneur: a discourse analysis of research texts on women entrepreneurship", Dissertation Series, No. 15, Jönköping International Business School, Jönköping.

Ajzen, I. (2002), "Perceived behavioral control, self-efficacy, locus of control, and the theory of planned behavior", Journal of Applied Social Psychology, Vol. 32 No. 4, pp. 665-683.

Allen, I.E., Elam, A., Langowitz, N. and Dean, M. (2008), Global Entrepreneurship Monitor 2007 Report on Women and Entrepreneurship, The Center for Women's Leadership at Babson College, Babson Park, MA.

Arenius, P. and Minniti, M. (2005), "Perceptual variables and nascent entrepreneurship”, Small Business Economics, Vol. 24 No. 3, pp. 233-247.

Bandura, A. (1977), "Self-efficacy: toward a unifying theory of behavioral change", Psychological Review, Vol. 84 No. 2, pp. 191-215.

Barbosa, S., Gerhardt, M. and Kickul, J. (2007), "The role of cognitive style and risk preference on entrepreneurial self-efficacy and entrepreneurial intentions", Journal of Leadership \& Organizational Studies, Vol. 13 No. 4, pp. 86-104.

Baum, J.R. and Locke, E.A. (2004), "The relationship of entrepreneurial traits, skill, and motivation to subsequent venture growth", Journal of Applied Psychology, Vol. 89 No. 4, pp. 587-598.

Boyd, N.G. and Vozikis, G.S. (1994), "The influence of self-efficacy on the development of entrepreneurial intentions and actions", Entrepreneurship Theory \& Practice, Vol. 18 No. 4, pp. 63-77.

Brindley, C. (2005), "Barriers to women achieving their entrepreneurial potential: women and risk", International Journal of Entrepreneurial Behaviour \& Research, Vol. 11 No. 2, pp. 144-161.

Brockhaus, R.H. (1980), "Risk taking propensity of entrepreneurs", Academy of Management Journal, Vol. 23 No. 3, pp. 509-520.

Bruni, A., Gherardi, S. and Poggio, B. (2004), "Entrepreneur-mentality, gender and the study of women entrepreneurs", Journal of Organizational Change Management, Vol. 17 No. 3, pp. 256-268.

Brush, C.G., Carter, N.M., Gatewood, E.J., Greene, P.G. and Hart, M.M. (2006), "Introduction: the Diana Project International”, in Brush, C.G., Carter, N.M., Gatewood, E.J., Greene, P.G. and Hart, M.M. (Eds), Growth Oriented Women Entrepreneurs and Their Businesses: A Global Research Perspective, Edward Elgar Publishers, Cheltenham, pp. 3-22.

Busenitz, L.W. (1999), "Entrepreneurial risk and strategic decision making: it's a matter of perspective", The Journal of Applied Behavioral Science, Vol. 35 No. 3, pp. 325-340.

Busenitz, L.W. and Barney, J.B. (1997), "Differences between entrepreneurs and managers in large organizations: biases and heuristics in strategic decision-making", Journal of Business Venturing, Vol. 12 No. 1, pp. 9-30.

Buttner, E.H. and Moore, D.P. (1997), "Women's organizational exodus to entrepreneurship: self-reported motivations and correlates with success", Journal of Small Business Management, Vol. 35 No. 1, pp. 34-46.

Cardon, M.S., Wincent, J., Singh, J. and Drnovsek, M. (2009), "The nature and experience of entrepreneurial passion", Academy of Management Review, Vol. 34 No. 3, pp. 511-532. 
$\underset{7,1}{\text { IJGE }}$

Cantillon, R. (1931), Essai sur la nature du commerce en général, edited and translated by Higgs, H., Macmillan, London.

Cardon, M.S., Zietsma, C., Saparito, P., Matherne, B.P. and Davis, C. (2005), “A tale of passion: new insights into entrepreneurship from a parenthood metaphor", Journal of Business Venturing, Vol. 20 No. 1, pp. 23-45.

Carter, N., Gartner, W., Shaver, K. and Gatewood, E. (2003), “The career reasons of nascent entrepreneurs", Journal of Business Venturing, Vol. 18 No. 1, pp. 13-39.

Carter, S., Shaw, E., Lam, W. and Wilson, F. (2007), "Gender, entrepreneurship and bank lending: the criteria and processes used by bank loan officers in assessing applications", Entrepreneurship Theory \& Practice, Vol. 31 No. 3, pp. 427-444.

Chen, C.C., Greene, P.G. and Crick, A. (1998), "Does entrepreneurial self-efficacy distinguish entrepreneurs from managers?”, Journal of Business Venturing, Vol. 13 No. 4, pp. 295-316.

Dabic, M., Daim, T., Bayraktaroglu, E., Novak, I. and Basic, M. (2012), "Exploring gender differences in attitudes of university students towards entrepreneurship: an international survey”, International Journal of Gender and Entrepreneurship, Vol. 4 No. 3, pp. 316-336.

Delmar, F. and Davidsson, P. (2000), "Where do they come from? Prevalence and characteristics of nascent entrepreneurs", Entrepreneurship \& Regional Development, Vol. 12 No. 1, pp. 1-23.

Dickerson, A. and Taylor, M.A. (2000), "Self-limiting behavior in women: self esteem and self efficacy as predictors", Group and Organization Management, Vol. 25 No. 2, pp. 191-210.

Fielden, S.L., Davidson, M.J., Dawe, A.J. and Makin, P.J. (2003), "Factors inhibiting the economic growth of female owned small businesses in North West England", Journal of Small Business and Enterprise Development, Vol. 10 No. 2, pp. 152-166.

Fletcher, D. (2010), “Life-making or risk taking”? Co-preneurship and family business start-ups", International Small Business Journal, Vol. 28 No. 5, pp. 452-469.

Gatewood, E.J., Shaver, K.G., Powers, J.B. and Gartner, W.B. (2002), “Entrepreneurial expectancy, task effort, and performance", Entrepreneurship Theory \& Practice, Vol. 27 No. 2, pp. 187-206.

Greene, P.G., Brush, C.G. and Gatewood, E.J. (2006), "Perspectives on women entrepreneurs past findings and new directions”, in Minniti, M. (Ed.), Entrepreneurship: The Engine of Growth, Praeger Publishers, Westport, CT, Vol. 1, pp. 181-204.

Hébert, R.F. and. Link, A.N. (1989), "In search of the meaning of entrepreneurship”, Small Business Economics, Vol. 1 No. 1, pp. 39-49.

Hofstede, G. (2001), Cultur's Consequences: Comparing Values, Behaviors, Institutions and Organizations Across Nations, 2nd ed., Sage, Thousand Oaks, CA.

Hofstede, G., Hofstede, G.J. and Minkov, M. (2010), Cultures and Organizations: Software of the Mind, McGraw-Hill, New York, NY.

Karakowsky, L. and Elangovan, A.R. (2001), "Risky decision making in mixed-gender teams Whose risk tolerance matters?”, Small Group Research, Vol. 32 No. 1, p. 94-111.

Keh, H.T., Foo, M.D. and Lim, B.C. (2002), "Opportunity evaluation under risky conditions: the cognitive processes of entrepreneurs”, Entrepreneurship Theory \& Practice, Vol. 27 No. 2, pp. 125-148.

Kelley, D.J., Brush, C.G., Greene, P.G. and Litovsky, Y. (2011), Global Entrepreneurship Monitor, 2010 Women's report, The Center for Women's Leadership at Babson College, Babson Park, MA.

Kelley, D.J., Singer, S. and Herrington, M. (2012), Global Entrepreneurship Monitor, 2011 Global Report, Babson College, Babson Park, MA, USA. 
Kirkwood, J. (2009), "Is a lack of self-confidence hindering women entrepreneurs?", International Journal of Gender and Entrepreneurship, Vol. 1 No. 2, pp. 118-133.

Krueger, N.F. and Dickson, P.R. (1994), "How believing in ourselves increases risk taking: perceived self-efficacy and opportunity recognition”, Decision Sciences, Vol. 25 No. 3, pp. 385-400.

Krueger, N.F., Reilly, M.D. and Carsrud, A.L. (2000), "Competing models of entrepreneurial intentions", Journal of Business Venturing, Vol. 15 Nos 5/6, pp. 411-432.

Langowitz, N. and Minniti, M. (2007), "The entrepreneurial propensity of women", Entrepreneurship Theory \& Practice, Vol. 31 No. 3, pp. 341-364.

Liles, P.R. (1974), New Business Ventures and Entrepreneurship, Irwin, R.D. (Ed.), Homewood, Illinois.

Ljunggren, E. and Kolvereid, L. (1996), "New business formation: does gender make a difference?", Women in Management Review, Vol. 11 No. 4, pp. 3-12.

Low, M.B. and MacMillan, I.C. (1988), "Entrepreneurship: past research and future challenges", Journal of Management, Vol. 14 No. 2, pp. 139-161.

Marlow, S., Henry, C. and Carter, S. (2009), "Exploring the impact of gender upon women's business ownership: introduction", International Small Business Journal, Vol. 27 No. 2, pp. 139-147.

Marlow, S. and McAdam, M. (2011), "Analyzing the influence of gender upon high-technology venturing within the context of business incubation", Entrepreneurship Theory \& Practice, Vol. 36 No. 4, pp. 655-676.

Marlow, S. and Patton, D. (2005), "All credit to men? Entrepreneurship, finance and gender", Entrepreneurship Theory \& Practice, Vol. 29 No. 6, pp. 717-735.

Mills, C. and Pawson, K. (2012), "Integrating motivation, risk-taking and self-identity: a typology of ICT enterprise development narratives", International Small Business Journal, Vol. 30 No. 5, pp. 584-606.

Minniti, M., Arenius, P. and Langowitz, N. (2005), 2004 Global Entrepreneurship Monitor Special Topic Report: Women and Entrepreneurship, Center for Women's Leadership at Babson College, Babson Park, MA.

Minniti, M. and Nardone, C. (2007), "Being in someone else's shoes: the role of gender in nascent entrepreneurship", Small Business Economics, Vol. 28 No. 1, pp. 223-238.

Monsen, E. and Urbig, D. (2009), "Entrepreneurs and perceptions of compound risk: moderating effects of efficacy and control beliefs", Frontiers of Entrepreneurship Research, Vol. 29 No. 6, pp. 1-15.

Morris, M.H., Miyasaki, N.N., Watters, C.E. and Coombes, S.M. (2006), "The Dilemma of growth: understanding venture size choices of women entrepreneurs", Journal of Small Business Management, Vol. 44 No. 2, pp. 221-244.

Reynolds, P.D. (2000), "National panel study of US business startups: background and methodology", Advances in entrepreneurship, firm emergence and growth, Vol. 4 No. 1, pp. 153-227.

Reynolds, P.D. (2011), New Firm Creation: A Global Assessment of national, Contextual, and Individual Factors, Now Publishers, Hanover.

Ritchie, R.L. and Brindley, C.S. (2001), “The information-risk conundrum”, Marketing Intelligence \& Planning, Vol. 19 No. 1, pp. 29-37.

Segal, G., Borgia, D. and Schoenfeld, J. (2005), "The motivation to become an entrepreneur", International Journal of Entrepreneurial Behaviour \& Research, Vol. 11 No. 1, pp. 42-57. 
$\underset{7,1}{\text { IJGE }}$

Sexton, D. and Bowman-Upton, N. (1990), "Female and male entrepreneurs: psychological characteristics and their role in gender-related discrimination", Journal of Business Venturing, Vol. 5 No. 1, pp. 29-36.

Shaver, K.G. and Scott, L.R. (1991), "Person, process, choice: the psychology of new venture creation”, Entrepreneurship Theory \& Practice, Vol. 16 No. 2, pp. 23-45.

Simon, M., Houghton, S.M. and Aquino, K. (2000), "Cognitive biases, risk perception, and venture formation: how individuals decide to start companies", Journal of Business Venturing, Vol. 15 No. 2, pp. 113-134.

Sitkin, S.B. and Pablo, A.L. (1992), "Reconceptualizing the determinants of risk behavior", Academy of Management Review, Vol. 17 No. 1, pp. 9-38.

Sitkin, S.B. and Weingart, L.R. (1995), "Determinants of risky decision making behavior: a test of the mediating role of risk perceptions and risk propensity", Academy of Management Journal, Vol. 38 No. 6, pp. 1573-1592.

Smilor, R.W. (1997), "Entrepreneurship: reflections on a subversive activity", Journal of Business Venturing, Vol. 12 No. 5, pp. 341-346.

Vallerand, R.J., Mageau, G.A., Ratelle, C., Leonard, M., Blanchard, C., Koestner, R. and Gagne, M. (2003), "Les passions de l'ame: on obsessive and harmonious passion", Journal of Personality and Social Psychology, Vol. 85 No. 4, pp. 756-767.

Vejsiu, A. (2011), "Incentives to self-employment decision in Sweden", International Review of Applied Economics, Vol. 25 No. 4, pp. 379-403.

Verheul, I. and Thurik, A.R. (2001), "Start-up capital: does gender matter?", Small Business Economics, Vol. 16 No. 4, pp. 329-345.

Verheul, I., Uhlaner, L. and Thurik, A.R. (2005), "Business accomplishments, gender and entrepreneurial self-image”, Journal of Business Venturing, Vol. 20 No. 4, pp. 483-518.

Weber, E.U., Blais, A.R. and Betz, N.E. (2002), “A domain-specific risk-attitude scale: measuring risk perceptions and risk behaviors”, Journal of Behavioral Decision Making, Vol. 15 No. 4, pp. 263-290.

Wilson, F., Kickul, J. and Marlino, D. (2007), "Gender, entrepreneurial self-efficacy, and entrepreneurial career intentions: implications for entrepreneurship education”; Entrepreneurship Theory \& Practice, Vol. 31 No. 3, pp. 387-406.

Winn, J. (2005), "Women entrepreneurs: can we remove the barriers?", International Entrepreneurship and Management Journal, Vol. 1 No. 3, pp. 381-397.

Wood, R.E. and Bandura, A. (1989), "Social cognitive theory of organizational management", Academy of Management Review, Vol. 14 No. 3, pp. 361-384.

Zhao, H., Seibert, S.E. and Hills, G.E. (2005), "The mediating role of self-efficacy in the development of entrepreneurial intentions", Journal of Applied Psychology, Vol. 90 No. 6, pp. 1265-1272.

Zinkhan, G.M. and Karande, K.W. (1991), "Cultural and gender differences in risk-taking behavior among American and Spanish decision makers”, Journal of Social Psychology, Vol. 131 No. 5, pp. 741-742.

Corresponding author

Cecilia Dalborg can be contacted at: cecilia.dalborg@miun.se

For instructions on how to order reprints of this article, please visit our website:

www.emeraldgrouppublishing.com/licensing/reprints.htm

Or contact us for further details: permissions@emeraldinsight.com 